\title{
Eksistensi Bahasa Indonesia di Sekolah Menengah Atas
}

\author{
Nana Triana Winata ${ }^{1 *}$, Jasril $^{2)}$ \\ nana.winata@unwir.ac.id ${ }^{1)}$, jasrilpiliang2000@gmail.com ${ }^{2)}$ \\ Universitas Wiralodra, Indramayu ${ }^{11}$, STKIP YDB Lubuk Alung, Padang ${ }^{2)}$
}

\begin{abstract}
Abstrak. Sebagian Sekolah Menengah Atas (SMA) khususnya di SMAN 1 Sindang banyak menggunakan bahasa Inggris pada papan pengumuman atau imbauan yang ada di sekolah. Menurut Perpres Nomor 63 Tahun 2019 Pasal 23 mengenai Bahasa pengantar dalam pendidikan nasional, dalam lingkungan pendidikan harus menggunakan bahasa Indonesia baik secara lisan atau tulisan. Tujuan dalam penelitian ini adalah (1) mengetahui eksistensi penggunaan bahasa Indonesia ragam tulis pada slogan, papan pengumuman, dan kata imbauan yang ada di SMAN 1 Sindang; dan (2) Pembinaan penggunaan bahasa Indonesia di SMA. Eksistensi bahasa Indonesia masih kalah dengan penggunaan bahasa Inggris ragam tulis yang ada di sekolah tersebut. Seperti halnya, penggunaan kata "class" pada papan pengumuman yang menunjukkan ruangan belajar yang ada di sekolah tersebut, seharusnya sesuai dengan Perpres Nomor 63 Tahun 2019 Pasal 23 tentang Bahasa pengantar dalam pendidikan nasional. Setiap sekolah harus menggunakan bahasa Indonesia, baik ragam lisan dan ragam tulis, semua pengumuman secara tertulis harus menggunakan bahasa Indonesia. Oleh karena itu, untuk penulisan kata "class" harus menggunakan bahasa Indonesia yaitu "kelas".
\end{abstract}

Kata kunci: Eksistensi Bahasa Indonesia, kualitatif

\section{Pendahuluan}

Era industri 4.0 secara tidak sadar mendorong pengguna bahasa untuk menguasai bahasa asing. Pada umumnya penutur menguasai bahasa Inggris sebagai bahasa internasional. Di beberapa kota besar kalangan penutur mulai mengesampingkan bahasa Indonesia, penutur lebih bangga menggunakan bahasa asing. Ketika dikaitkan dengan industri 4.0 khususnya pada media sosial, masyarakat penutur bahasa ragam tulis lebih mementingkan penggunaan bahasa Inggris ketika mereka mengunggah status pada media sosial (whatsapps, twitter, facebook, dan lain-lain).

Penggunaan bahasa Indonesia di ruang publik mulai tergeser oleh penggunaan bahasa asing. Penutur bahasa, baik ragam lisan maupun tulis lebih mementingkan penggunaan bahasa asing daripada menggunakan bahasa Indonesia. Khususnya, kalangan milenial lebih sering menggunakan campur kode bahasa asing dan bahasa Indonesia. Eksistensi bahasa Indonesia di kalangan milenial mulai tergeser, khususnya penggunaan bahasa Indonesia di ruang publik. Penutur bahasa mulai membiasakan menggunakan campur kode bahasa asing, baik itu ketika berbahasa secara lisan maupun tulisan.

Pada era globalisasi pemerintah mendorong beberapa sekolah agar memiliki standar internasional yang dicantumkan dalam UU No 20 Tahun 2003 tentang Sisdiknas Pasal 50 ayat (3) yang berisi, "Pemerintah dan/atau pemerintah daerah menyelenggarakan sekurang-kurangnya satu satuan pendidikan pada semua jenjang pendidikan untuk dikembangkan menjadi satuan pendidikan yang bertaraf internasional". Adanya Sekolah Bertaraf Internasional (SBI) mengharuskan menggunakan bahasa asing yaitu bahasa Inggris sebagai bahasa pengantar pendidikan yang ada di Sekolah Bertaraf Internasional (SBI).

Sekolah tersebut mendorong semua pihak yang terlibat baik itu tenaga kependidikan, tenaga pengajar, dan peserta didik diharuskan menggunakan bahasa Inggris dalam lingkungan 
sekolah. Guru pun ketika melakukan pembelajaran di kelas menggunakan bahasa Inggris. Selain itu, kurikulum yang digunakan juga seharusnya kurikulum internasional yaitu Kurikulum Cambridge, International Baccalaureate (IB) atau International General Certificate of Secondary Education (IGCSE).

Ketika dalam pembalajaran di kelas, guru harus menguasai bahasa Inggris, karena bahasa Inggris merupakan bahasa pengantar dalam pembelajaran. Secara tidak langsung mengubah pola pikir siswa untuk diwajibkan bisa berbahasa Inggris dan menggeserkan bahasa Indonesia. Banyak siswa yang ada di SBI yang menggunakan kurikulum Cambridge, International Baccalaureate (IB) atau International General Certificate of Secondary Education (IGCSE), justru tidak pandai menggunakan bahasa Indonesia baik secara lisan maupun tulisan. Padahal secara kependudukan siswa tersebut adalah Warga Negara Indonesia (WNI) bukanlah Warga Negara Asing (WNA).

Adanya SBI secara tidak langsung menggeserkan peran bahasa Indonesia di lingkungan pendidikan yaitu di sekolah. Sekolah mulai mengganti imbauan atau pengumuman menggunakan bahasa Inggris daripada menggunakan bahasa Indonesia. Peran bahasa Indonesia mulai tergeser oleh bahasa Inggris, ketika pada sebuah imbauan atau pengumuman penulisan bahasa Inggris lebih besar daripada bahasa Indonesia.

Sekolah bertaraf internasional bukan berarti harus mengubah kedudukan atau fungsi dari bahasa Indonesia sebagai lambang bahasa negara. Salah satu sekolah yang ada di Indramayu pun mulai terhegemoni oleh bahasa Inggris. Terlihat pada sebuah tulisan yang ada di lingkungan SMAN 1 Sindang yang lebih menonjolkan bahasa Inggris daripada bahasa Indonesia. Tidak heran SMA tersebut menonjolkan bahasa Inggris, karena sekolah tersebut termasuk dalam sekolah unggulan yang ada di Kabupaten Indramayu, Jawa Barat.

Fenoma tersebut sudah tidak asing di sekolah yang unggul atau diistilahkan dengan sekolah favorit yang ada di mana pun akan menonjolkan penggunaan bahasa Inggris daripada bahasa Indonesia, sehingga sekolah tersebut dapat terlihat sebagai sekolah yang bertaraf internasional.

Tujuan dalam penelitian ini adalah mengetahui eksistensi penggunaan bahasa Indonesia ragam tulis pada pengumuman yang ada di SMAN 1 Sindang dan pembinaan penggunaan bahasa Indonesia di SMA.

\section{Metode}

Penelitian kualitatif merupakan penelitian interpretif, yang di dalamnya peneliti terlibat dalam pengalaman yang berkelanjutan dan terus-menerus dengan para partisipan. Keterlibatan inilah yang nantinya memunculkan serangkaian isu-isu strategi, etis, dan personal dalam proses penelitian kualitatif (Locke dalam Creswell, 2015:229). Penelitian ini menemukan fenomena bahasa Indonesia di ruang publik. Penelitian ini mendeskripsikan eksistensi bahasa Indonesia di lingkungan SMAN 1 Sindang yang lebih menonjolkan basaha Inggris daripada bahasa Indonesia. Lokasi penelitian ini di SMAN 1 Sindang yang beralamat di Jalan Letjend. M.T. Haryono, Sindang-Indramayu, Jawa Barat. Sekolah itu memiliki visi menjadi sekolah yang baik dalam implementasi religi, terdepan dalam prestasi, dan tertinggi dalam dedikasi pada tata kelola lingkungan sehat 


\section{Hasil dan Pembahasan}

Profil penggunaan bahasa Indonesia di SMAN 1 Sindang sudah cukup seimbang. Akan tetapi, terlalu menonjolkan bahasa Inggris dalam papan pengumuman atau dalam sebuah kalimat motivasi. Berdasarkan Undang-Undang Nomor 24 Tahun 2009 tentang Bendera, Bahasa, dan Lambang Negara, serta Lagu Kebangsaan Indonesia, tugas Badan Pengembangan dan Pembinaan Bahasa Kemendikbud adalah menjaga, merawat, dan memartabatkan bahasa negara yaitu bahasa Indonesia. Sesui dengan amanat UU tersebut seharusnya seluruh Warga Negara Indonesia (WNI) harus menjaga atau merawat bahasa Indonesia selama berada di lingkungan Republik Indonesia baik itu di lingkungan dinas, pariwisata, pendidikan, dan lingkungan yang lainnya.

Sebenarnya setiap warga negara Indonesia sudah paham tentang UU No 24 Tahun 2009. Akan tetapi, dalam praktiknya terkadang sangat sulit menggunakan bahasa Indonesia. Hal yang sering terjadi kekeliruan penggunaan frasa "Satuan Pengamanan (satpam)", masih banyak tempat umum yang menggunakan bahasa Inggris yaitu security. Hampir setiap sekolah yang memiliki pos keamanan menggunakan kata security daripada menggunakan akronim "satpam”. Secara tidak langsung hal seperti itu, menanamkan siswa yang ada di sekolah untuk menghapal kata security, sehingga siswa akan lebih bersahabat dengan bahasa asing tersebut.

Selain itu, hal yang lazim sering terjadi kekeliruan khususnya yang terjadi di SMAN 1 Sindang ini adalah adanya sebuah imbauan menggunakan bahasa Inggris. Seperti imbauan "say no to drugs" yang artinya "katakan tidak pada narkoba". Siswa sangat terasa asing jika ada sebuah imbauan yang menggunakan bahasa Indonesia, khsusnya imbauan tentang narkoba dan alkohol. Tidak hanya di SMAN 1 Sindang yang menggunakan imbauan dengan bahasa Inggris, hampir setiap sekolah yang mencantumkan imbauan tersebut lebih sering menggunakan imbauan bahasa Inggris "say no to drugs" atau "say no to alcohol".

Pihak yang terkait khususnya yang ada di sekolah belum dapat menerapkan amanat UU No. 24 Tahun 2009. Seharusnya pihak terkait harus mengubah semua imbauan dengan menggunakan bahasa Indonesia yaitu "katakan tidak kepada narkoba" atau "katakan tidak kepada alkohol". Ketika akan menyisipkan bahasa Inggris, harus menonjolkan atau penggunaan bahasa Indonesia lebih besar dari bahasa Inggris.

Tabel 1

Penggunaan Bahasa Inggris di SMAN 1 Sindang

\begin{tabular}{cll}
\hline No & Bahasa Indonesia & Bahasa Inggris \\
\hline 1. & Kelas & Class \\
2. & Katakan tidak kepada narkoba & Say no to drugs \\
3. & Katakan tidak kepada alkohol & Say no to alcohol \\
4. & Satuan pengamanan (satpam) & Security \\
5. & Kawasan dilarang merokok & No smoking area \\
6. & Selamat datang di rumah & Welcome to the house \\
7. & Ruang teori & Theory room \\
\hline 8. & Disiplin adalah kunci keberhasilan & Discipline is the key for your \\
& anda & success \\
\hline
\end{tabular}


Selain UU No. 24 Tahun 2009, sejalan dengan Perpres No. 63 Tahun 2009 Pasal 23 mengenai Bahasa pengantar dalam pendidikan nasional, dalam lingkungan pendidikan harus menggunakan bahasa Indonesia baik secara lisan maupun tulisan. Harus ada kesadaran untuk mementingkan atau menonjolkan bahasa Indonesia di ruang publik. Dalam lingkungan pendidikan harusnya menonjolkan penggunaan bahasa Indonesia, sehingga siswa lebih merasa bangga dalam menggunakan bahasa Indonesia. Sejalan dengan slogan dari Badan Pengembangan dan Pembinaan Bahasa, Kemendikbud yaitu "Utamakan Bahasa Indonesia, Lestarikan Bahasa Daerah, Kuasai Bahasa Asing”. Dari slogan tersebut, seluruh warga Indonesia harus mengutamakan bahasa Indonesia khususnya di ruang publik.

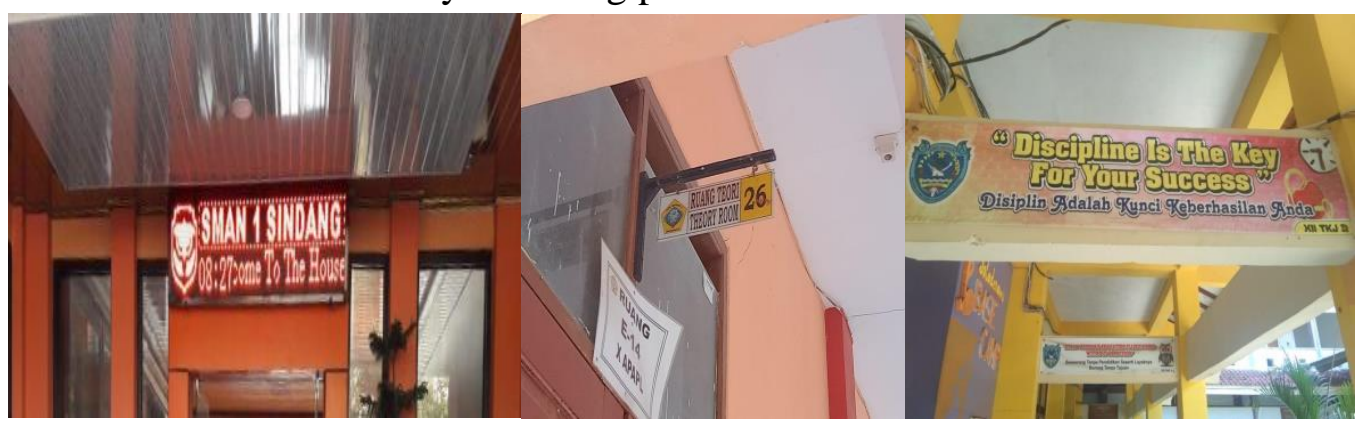

Gambar 1, penggunaan bahasa Inggris

Perlu diadakannya sosialisasi pembinaan bahasa Indonesia khsusnya di sekolah-sekolah yang ada di Indonesia untuk mengubah fenomena penggunaan bahasa Inggris menjadi bahasa Indonesia. Badan Pengembangan dan Pembinaan Bahasa melalui Balai Bahasa yang ada di tiap provinsi harus melakukan sosialisasi kepada pihak sekolah.

Sejalan dengan mata kuliah Pembinaan dan Pengembangan Bahasa Indonesia menyambangi sekolah-sekolah khususnya SMAN 1 Sindang untuk menyosialisasi penggunaan bahasa Indonesia di lingkungan sekolah. Ketika Sekolah Bertaraf Internasional (SBI), diberikan alternatif penggunaan bahasa pada imbauan yang ada di sekolah. Pembinaan tersebut memberikan arahan kepada pihak terkait untuk menonjolkan bahasa Indonesia daripada bahasa Inggris, sehingga alternatif penggunaannya "katakan tidak kepada narkoba" penulisannya harus lebih besar dari "say no to drugs". Ketika penggunaan bahasa sesuai dengan arahan tersebut, maka pihak sekolah sudah melaksanakan UU No. 24 Tahun 2009 dan Perpres No. 63 Tahun 2019, serta melaksanakan slogan dari Badan Pengembangan dan Pembinaan Bahasa. Dalam pengutamaan bahasa Indonesia di ruang publik semua pihak terkait harus saling membantu dalam menyosialisasikannya. Tanpa ada dukungan dari semua pihak maka akan terasa sulit menggunakan bahasa Indonesia di ruang publik.

\section{Simpulan}

Penggunaan bahasa Inggris di SMAN 1 Sindang masih sangat dominan daripada penggunaan bahasa Indonesia. Walaupun terdapat dua tulisan yang berbahasa Inggris dan Indonesia, tetapi penulisan bahasa Inggris lebih besar daripada penulisan bahasa Indonesia. Dilaksanakan sosialisasi atau pembinaan penggunaan bahasa Indonesia di SMAN 1 Sindang agar menggunakan bahasa Indonesia di ruang publik, sejalan dengan UU No. 24 Tahun 2009 dan Perpres No. 63 Tahun 2019 tentang Penggunaan bahasa Indonesia di ruang publik. 


\section{Daftar Pustaka}

Alwi, Hasan. 2003. “Tata Bahasa Baku Bahasa Indonesia”. Jakarta: Balai Pustaka.

Arifin, E. Zaenal, dkk. 2017. "Pembinaan dan Pengembangan Bahasa: Pada Era Teknologi Informasi". Tangerang: Pustaka Mandiri.

Creswell, John W. 2015. "Penelitian Kualitatif \& Desain Riset”. Yogyakarta: Pustaka Pelajar.

Moeliono, Anton M. 1981. "Pengembangan dan Pembinaan Bahasa: Ancangan Alternatif di dalam Perencanaan Bahasa". Jakarta: Djambatan.

Putri, Ria Anggari. 2018. "Peranan dan Penggunaan Bahasa Gaul terhadap Eksistensi Bahasa Indonesia di Media Sosial”. Prosiding Pembelajaran Bahasa dan Sastra Indonesia di Era Milenial. Universitas Pakuan.

Rizali, Ahmad, dkk. 2009. "Dari Guru Konvensional Menuju Guru Profesional”. Jakarta: PT Grasindo.

Sugiarto, Eko. 2017. “KITAB PUEBI-Pedoman Umum Ejaan Bahasa Indonesia”. Yogyakarta: ANDI.

Sugiyono. 2017. "Metode Penelitian \& Pengembangan: Research and Development". Bandung: Alfabeta.

Umar, Fatmah AR. 2011. "Eksistensi Bahasa Indonesia di Sekolah Berstandar Internasional (SBI). Dalam Prosiding Bahasa dan Sastra Indonesia (Konservasi dan Pendidikan Karakter). Universitas Negeri Semarang. 